\title{
Effects of High-Performance Work Practices (HPWPs) on Employee Performance: A Review Article
}

\author{
Charles Joseph Tawk \\ Meirc Training and Consulting Company, Dubai, UAE \\ Email: charles.tawk@gmail.com
}

How to cite this paper: Tawk, C.J. (2021). Effects of High-Performance Work Practices (HPWPs) on Employee Performance: A Review Article. Journal of Human Resource and Sustainability Studies, 9, 397-412. https://doi.org/10.4236/jhrss.2021.93025

Received: July 5, 2021

Accepted: August 21, 2021

Published: August 24, 2021

Copyright $\odot 2021$ by author(s) and Scientific Research Publishing Inc. This work is licensed under the Creative Commons Attribution International License (CC BY 4.0).

http://creativecommons.org/licenses/by/4.0/

\begin{abstract}
The main objective of this review article is to produce a comprehensible collection of existing resources in the literature to explore the relation between high-performance work practices (HPWPs) and organizational performance in an attempt to evaluate and abridge the ways through which HPWPs can improve organizational performance. Additionally, the aim is to reveal how high-performance work practices can influence the positive change in organizational performance as many studies results demonstrate that high-performance work practices can most of the time considerably envisage organizational performance. However, and even though high-performance work practices are deemed to have a great impact over organizational performance, this paper will not overlook HPWPs possible peripheral setbacks and will try to uncover some of HPWPs undesirable effects.
\end{abstract}

\section{Keywords}

High Performance Work Practices (HPWPs), Organizational Performance, High Performance Work Systems (HPWS), Individual Performance

\section{Introduction}

As soon as organizations realized the importance of employees, they started to search for a way to benefit from their huge capabilities. If employees are trained, motivated, and encouraged, they can differentiate organizations by increasing organizational creativity, innovation, productivity, and profitability (Lee, Mazzei, \& Kim, 2018). This focuses on human potential gave birth to people management within organizations, or in other words, what we call now "human resources management". Even though the importance of human abilities is not 
understood at companies' emersion era, nowadays, organizations know that employees' output can be improved through management tactics and practices leading to better organizational performance (Ibidunn, Osibanjo, Adeniji, Salau, \& Falola, 2015). These practices are mainly called "high performance work practices" (HPWPs) (Pittino, Visintin, Lenger, \& Sternad, 2016). "high performance work practices" (HPWPs) appeared in the United States in the nineties and were introduced to many industries such as textile and manufacturing (Karatepe \& Olugbade, 2016). However, HPWPs concept underwent several changes in its interpretation. At the beginning it focused on the individual discretionary efforts as a major instigator to organizational performance. Nowadays, the use of HPWPs is to improve both individuals' lives and organizational performance (Ashton \& Sung, 2002) and (Murphy, Torres, Ingram, \& Hutchinson, 2018). By adopting HPWPs substantial effects such as increased performance, productivity, and profits appeared on organizations. Naturally, many researchers attempted to cover this interesting topic, however most of those research and studies focused on how to connect HPWPs with organizational performance.

The purpose of this review article is to highlight the effects of high-performance work practices on organizational performance from the wide literature in an attempt to evaluate and abridge the ways through which HPWPs can improve organizational performance without overlooking HPWPs possible peripheral setbacks.

\section{Theory of High-Performance Work Practices}

From the time of the industrial revolution, researchers and business leaders have tried to describe and evaluate specific work-related practices and methods that can increase productivity and give a competitive edge to organizations. All the efforts exerted in this area gave birth to many terms such as "high-performance practices", "employee involvement", "employee participation" and "flexible work organizations". What is in common between all previously mentioned terms is that all of them are used to describe workplace practices that underline employees' contribution role in improving organizational performance. The relationship between HPWPs and organizational performance was mentioned and was found positively correlated by many researchers such as (Combs, Liu, Hall, \& Ketchen, 2006), (Shin \& Konrad, 2017), (Garg, 2019), and many others. The use of "high performance" assumes that employees' participation always has a positive impact on organizational productivity and performance (Parks, 1995). Recently, the most used term is "high performance work practices" which is related to the practices that could enhance both individual and organizational performance (Alatailat, Elrehail, \& Emeagwali, 2019). In general, HPWPs represent management manoeuvres to encourage employees' effort towards improved performance levels through flexibility and power transfer. Management tactics are often described as "high performance" practices that may raise em- 
ployees' productivity (Capelli \& Neumark, 2001) and (Ogbonnaya \& Valizade, 2018). Although, HPWPs are modern employee management practices, such as formal employee training, high pay levels, group-based performance pay and self-directed teams (Appelbaum, 2000) and (Karatepe \& Olugbade, 2016), it is claimed that increased implementation of HPWPs results in better performing organizations (Combs, Liu, Hall, \& Ketchen, 2006) and (Robineau, Ohana, \& Swaton, 2015). Best practices recipes and labels do not end; but it is not the number of practices that matter, but the way they are linked to performance. So as per Waqas (2017), there is no magic formula in this regard; it could be a combination of different practices that can deliver the desired results.

\section{The Relationship between HPWPs and Organizational Performance}

Despite the debate about high performance work practices definition, HPWPs are not considered as a new concept; they are simply work practices that can be intentionally presented to improve organizational performance. They may consist of a mixture of innovative human resources practices which will properly use employee knowledge, skills, and abilities with an aim to achieve organizational performance enhancements. Additionally, HPWPs affect employee engagement and their sense of accomplishment and can be seen as a set of human resource practices that give the organization a competitive advantage (Huselid, 1995) and (Albrecht, Bakker, Gruman, Macey, \& Saks, 2015). A broadly accepted definition is that HPWPs are a set of complementary work practices covering three broad areas. These broad areas, as per Sung and Ashton (2005), are: first, high employee involvement practices, second, human resources practices and third, reward and commitment practices. New strategic human resources practices encompass the three previously mentioned broad areas. Thus, the importance of human resources management and why it should be a strategic partner in successful organizations (Ulrich, 2016), and the value of adopting certain practices in improving organizational performance (Russell, Terborg, \& Powers, 1985) and (Obeidat, Mitchell, \& Bray, 2016). HPWPs represent a sophisticated concept with many mechanisms where most of them are linked to human resources processes such as: selection, training, evaluation, compensation (Boxall \& Purcell, 2000) and (Selden \& Sowa, 2015). This link between human resources management and high-performance work practices has implicitly treated both topics as substitutes for one another with respect to their relationship with the organization performance (Garg \& Lal, 2015). As a matter of fact, human resources core goal is to stimulate employees through defined practices to receive in return their best performance. HPWPs in human resources management are considered strategic practices especially when they produce desired and tangible results. Currently, there is a high focus on how human resources management (HRM) can systemize HPWPs and most importantly how to compile the productive ones into a system referred as "high performance work system" (HPWS). 
There is no doubt about the importance of HPWPs but the most significant matter is the adoption and application of those practices by management and specifically by HRM who mainly handle human relations and personal interactions within the organization (Saridakis, Lai, \& Cooper, 2017). However, the remaining question is the following: if HPWPs are embraced and applied, will it lead to increased organizational performance?

The concrete fact assuring the positive link between HPWPs and organizational performance was not easy to demonstrate at the begining. However, many researchers tried and succeeded like (Combs, Liu, Hall, \& Ketchen, 2006), (Obeidat, Mitchell, \& Bray, 2016), and (Garg, 2019) to demonstrate a progressive correlation between HPWPs and organizational performance. They mentioned in their analysis that there is no doubt about the existence of such relationship whereby organizations can increase employee's performance by implementing HPWPs. Combs, Liu, Hall, and Ketchen (2006) also mentioned that according to strategic human resources theory, the mediators that drive the relation between HPWPs, which should be formalized through organizational systems known as high performance work practices systems, and performance are: research design, context, and organizational strategy. Their analysis showed an increase of 20 standardized units for each unit increase in HPWP use i.e., once HPWPs are applied, organizations who implement them can have $20 \%$ increase in their performance in comparison to the previous performance. Several researchers demonstrated the same. The positive effects of HPWPs on individual and organizational performance are listed in Table 1 below.

One cannot cover the subject of high-performance work practices without plunging into the depth of the practices affecting areas like behaviors and attitudes. Therefore, it is essential to identify and enumerate some of the high-performance work practices that can generate results and increase performance at the individual and organizational level. In this regard, Murphy, Torres, Ingram, and Hutchinson (2018) identified a set of 13 HPWPs specifically for the hospitality sector. Before Murphy and his colleagues, Guest (2000) identified 18 practices in his HPWPs study. Later Guest and his colleagues Michie, Conway, and Sheehan (2003) extended HPWPs constituents to reach 48 items. Additionally, through their research, and after defining the three broad areas "high involvement, human resources practices and reward and commitment", Sung and Ashton (2005) identified 35 high performance work practices reaching interesting findings and showing a strong link between those practices and the improvement of organizational performance. Sung and Ashton (2005) used indicators such as productivity and profitability to show this relationship. Listing some of those practices will be valuable especially in comparing them to the existing organizational practices and even in selecting few to apply in one's organization in the near future with the intention of comparing performance results before and after their implementation. Furthermore, several scholars such as Thompson (2000), Kling (1995), Sung and Ashton (2005) and others tried to enumerate HPWPs; however, 
Table 1. The positive effects of HPWPs on individual and organizational performance.

\begin{tabular}{|c|c|c|}
\hline & Effects & Author/s \\
\hline & $\begin{array}{l}\text { Authors of this study used a meta-analysis } \\
\text { to demonstrate without any doubt the } \\
\text { positive relation between HPWPs and } \\
\text { organizational performance. }\end{array}$ & $\begin{array}{c}\text { (Combs, Liu, } \\
\text { Hall, \& Ketchen, 2006) }\end{array}$ \\
\hline & $\begin{array}{l}\text { The conclusions of this study favor the } \\
\text { positive correlation between HPWPs and } \\
\text { organizational performance. }\end{array}$ & $\begin{array}{l}\text { (Obeidat, Mitchell, } \\
\text { \& Bray, 2016) }\end{array}$ \\
\hline & $\begin{array}{l}\text { The results of this study show that } \\
\text { HPWPs constructively and substantially } \\
\text { determine employees performance. }\end{array}$ & $\begin{array}{c}\text { (Akhtar, Nawaz, } \\
\text { Mahmood, \& Shahid, 2016) }\end{array}$ \\
\hline & $\begin{array}{l}\text { The two authors of this article advice } \\
\text { management to invest in HPWPs as they } \\
\text { enable employees to manage successfully } \\
\text { different work-related challenges. }\end{array}$ & (Safavi \& Karatepe, 2018) \\
\hline $\begin{array}{l}\text { High-Performance } \\
\text { Work Practices } \\
\text { (HPWPs) }\end{array}$ & $\begin{array}{l}\text { This study found proofs that the applied } \\
\text { HPWPs through a system have a positive } \\
\text { effect on organizational results such as } \\
\text { performance, efficiency, and income. }\end{array}$ & $\begin{array}{l}\text { (Mihail, Mac Links, \& } \\
\text { Sarvanidis, 2013) }\end{array}$ \\
\hline & $\begin{array}{l}\text { In general, this article confirms that } \\
\text { HPWPs have mostly a positive impact on } \\
\text { job satisfaction and consequently on } \\
\text { individual performance. }\end{array}$ & (Berg, 1999) \\
\hline & $\begin{array}{l}\text { This researcher suggested in his study that } \\
\text { once HPWPs are implemented properly, } \\
\text { the standard deviations of } 23 \% \text { and } 21.9 \% \\
\text { for total returns on non-cash items and } \\
\text { turnover are shown correspondingly. }\end{array}$ & (Huselid, 1995) \\
\hline & $\begin{array}{l}\text { These two scholars stated that if high } \\
\text { performance work practices are selected } \\
\text { carefully and systematically, they will result } \\
\text { in employee's positive attitude and } \\
\text { behavior and they will further constructively } \\
\text { affect organizational performance. }\end{array}$ & (Beck \& Wilson, 2000) \\
\hline
\end{tabular}

despite the difference in the number of their suggested practices all agreed to divide the practices into three categories or sets. The first set of HPWPs are common involvement practices such as circulating clear information on organizational performance and strategy, providing employees with a copy of the business plan and targets, internal staff surveys, self-managed teams, and continuous improvement. The second set of HPWPs are mainly human resources practices that include: annual appraisal, feedback on job performance, reviewing vacancies, recruitment, preparing employees' training needs, continuous skills development, personnel diversity, mentoring and quality assurance. The third set of HPWPs are common reward and commitment practices such as pay for performance, profit-sharing, share options, flexible job descriptions, flexible working hours, flexible work locations, job rotation, work life balance policies, free meals, 
gifts, health packages and benefits covering family members. Most of the suggested practices were linked to increased performance after testing them in organizations located in many countries and by using different study methods. The studies showed that HPWPs may also be more effective when grouped together in bundles (Ogbonnaya \& Valizade, 2018). Many "quantifiable" benefits have been acknowledged such as increased sales, increased market value, greater levels of employee satisfaction and commitment, and development of trust in work relations. These benefits can also be accompanied by lower levels of employees' turnover. Another longitudinal study for Tregaskis, Daniels, Glover, Butler and Meyer (2013) suggested that HPWPs can improve working conditions which will lead to improvements in motivation, knowledge, skills, and productivity. The same study further indicates that after the implementation of selected HPWPs, employees reported increased levels of job satisfaction, commitment, positive attitudes toward job security and improved management-employee communications. On the other hand, the qualitative data suggested that the changes in team working and training were perceived positively. Even though, occasionally HPWPs were associated simultaneously with increases in workload and negative experiences for some employees, the intensification effects were temporarily mitigated by skill development and increase in bonuses and pay. Another important finding was the sustainability of high-performance levels when HPWPs were implemented. Usually, the increase in performance is temporary in the workplace since it is generally guided by management intervention and well monitored to achieve predefined targets. However, the study of Tregaskis, Daniels, Glover, Butler and Meyer (2013) showed that while implementing HPWPs the impact on performance was not momentary or unstable. Therefore, the performance did not fell back to previous levels after implementing HPWPs and employees did not withdraw their discretionary efforts and were capable to meet new targets. On the contrary, a reciprocal management-employee exchange environment was generated through the implementation of HPWPs. Lots of research and studies dealt with the same subject, for instance, Sofijanova and Zabijakin-Chatleska (2013) found again in their analysis that although some practices have stronger links to performance than others, their results provide significant and practical support that investments in HPWPs are vital and can assist companies in improving overall performance. Thus, HPWPs' impact on organizational performance is not only statistically significant, but managerially relevant. Additionally, Nasurdin, Ling and Khan (2018) study revealed that HPWPs subsidiarily impinge on employee's turnover intent since the application of HPWPs by employers boosted their commitment. That commitment along with a genuine performance evaluation and fair compensation were found to be important influencers of employee retention and performance. In their meta-analysis Combs, Liu, Hall, and Ketchen (2006) claimed that once HPWPs are integrated in a system (HPWP systems) they will have stronger organizational performance effects than individual HPWPs and can be considered as a mod- 
erator of the total HPWP-organizational performance relationship. Therefore, the recent practices and research have moved their concentration from individual HPWPs toward HPWP systems (Wright \& Boswell, 2002) and (Ketchen Jr, Crook, Todd, Combs, \& Woehr, 2017). Present evidence does not support the argument that the relationship between HPWPs and organizational performance is affected by the choice of measures (Huselid, 1995), and (Wright, Gardner, Moynihan, \& Allen, 2005). As per the contextual moderator of the HPWP and organizational performance relationship; Combs, Liu, Hall, and Ketchen (2006) and (Hartnell, Ou, Kinicki, Choi, \& Karam, 2019) claimed that the effect among manufacturers is almost twice as large as among service organizations since manufacturers depend on complex machinery and standardized procedures where HPWPs are easily implemented and measured through systems. The need for HPWPs to aid adaptation is less among services because they are less burdened by complex machinery (Lawler, Mohran, \& Ledford, 1995). An additional reason why HPWPs affect manufacturers more is that the full range of productive outcomes is largely under their control, and because the HPWPs are potentially influenced by customers in the service sector (Bowen, 1986) and (Karatepe \& Vatankhah, 2015). The above does not emphasize only the importance of HPWPs selection, but it also affirms that the selection of such practices depends on the sector and the size of the organization as it will be demonstrated later. $\mathrm{Wu}$ (2011) studied the effects of HPWPs application on different organization sizes namely small, medium, and large organizations. Wu (2011) found that although the implementation of effective HR practices such as HPWPs in small sized firms is limited, one possible interpretation is that the lack of HPWPs in such firms only prevents them from the positive outcomes that usually accompany such implementation. However, few studies reported a positive relationship between HPWPs and performance in small sized firms such as the relationship between training and productivity. Faems, Sels, De Winne, and Maes (2005) combined in their research several HPWPs together like training, compensation, career management and performance management and found that those practices are individually related to labor productivity in small-sized firms. Additionally, Pittino, Visintin, , Lenger and Sternad (2016) found that high performance work practices in small family firms play a good role in employees motivation, commitment, retention, and performance even if these businesses depend less on official HPWPs. Alternatively, Delery's (1998) mentioned in his research that in medium-sized firms the right choice of HPWPs is critical for improving firms' performance and results. Such choices may be crucial because medium-sized firms are in a development stage where the main concern is to target problems in order to help these firms grow (Greiner, 1972) and (Rauch \& Hatak, 2016). As per large-sized firms there are similar findings with the small-sized firms where in both, the implementation of HPWPs resulted in improvement of their employee's performance. However, in large-sized firms, HPWPs need a platform or a system to be more effective. Hence, significantly 
higher levels of performance were found in large firms with a strong human resources management (HRM) system (Wu, Hoque, Bacon, \& Bou Llusar, 2015). This clearly demonstrates that a strong HRM system that contains bundles of well selected HPWPs is more likely to have a greater impact on performance (Bowen \& Onsoff, 2004) and (Garg, 2019). Therefore, it is useful to emphasize again that the "best" set of HPWPs in a given organization can depend on many criteria and steps preceding their implementation. Then, one of the fundamental steps is inserting HPWPs in the organizational strategy and systems in order to enhance organizational performance (McAlearney, Hefner, Robbins, \& Garman, 2016). This enhancement of organizational performance must reach all aspects of the organization, especially human resource management. This is why strategic human resources management (SHRM) theories assert that HPWPs affect organizational performance by increasing employees' knowledge, skills and abilities, by empowering and motivating them to apply their competencies in the workplace. Applying HPWPs in an organization provides employees with better probabilities of developing and improving their skills than an organization which does not apply them (Ogbonnaya \& Valizade, 2018). HPWPs can also increase motivation between employees encouraging them to perform better. As a result, HPWPs can benefit organizations in higher performance which can generate additional profits to both employer and employee (Godard, 2004) and (Shin \& Konrad, 2017).

\section{The Possible Peripheral Setbacks}

Even though, most studies associate HPWPs with enhanced productivity, improved incomes, and decreased employees' turnover, few only have focused on the negative effects of HPWPs such as employee stress that may result from bigger employee utilization. Recently, many researchers discovered that HPWPs might also be linked to negative employee outcomes, increased anxiety, and job dissatisfaction (Wood, Van Veldhoven, Croon, \& de Menezes, 2012) and (Topcic, Baum, \& Kabst, 2016). Additionally, management practices like HPWPs can produce negative consequences for employees when things like emotional exhaustion are considered, rather than the typical job attitudes. The negative effects of HPWPs application are listed in Table 2 below.

Additionally, there is still no definite best set of practices or even research proof that HPWPs can equally impact the performance of different units within the same organization or even different companies within an identical sector etc. That being said, high performance work practices understanding, adoption and impact vary between countries, sectors and organizations, and may sometimes include some negative effects on organizational performance. Defenders of the positive HPWPs might have not covered the negative aspects of HPWPs effects on individuals. Thus, few studies tackled the ways HPWPs can impact employees' feelings despite its great impact on their results. The major focus was on 
Table 2. The negative effects of HPWPs application.

\begin{tabular}{|c|c|c|}
\hline & Negative effect & Author/s \\
\hline & $\begin{array}{l}\text { These two authors examined in their study two } \\
\text { counteracting perceptions on how HPWPs } \\
\text { relate to the emotional exhaustion dimension of } \\
\text { burnout. This critical viewpoint anticipated that } \\
\text { HPWPs increase the job demands and burnout } \\
\text { consequently. Therefore, in organizations that } \\
\text { reported that more employees were covered by } \\
\text { HPWPs, employees reported higher levels of } \\
\text { job demands and this was also associated } \\
\text { with more emotional exhaustion. }\end{array}$ & $\begin{array}{l}\text { (Kroon, Van de Voorde, } \\
\& \\
\text { Van Veldhoven, 2009) }\end{array}$ \\
\hline & $\begin{array}{l}\text { This article found that there is more evidence } \\
\text { that management practices like HPWPs act as } \\
\text { contextual stressors that result in an } \\
\text { intensification of job demands. }\end{array}$ & $\begin{array}{c}\text { (Noblet \& } \\
\text { Rodwell, 2008) }\end{array}$ \\
\hline \multirow[t]{4}{*}{$\begin{array}{l}\text { High Performance } \\
\text { Work practices } \\
\text { (HPWPs) }\end{array}$} & $\begin{array}{l}\text { states that burnout accompanying HPWPs can } \\
\text { lead to the reduction of performance and is } \\
\text { considered as one of the most frequent } \\
\text { negative consequences. }\end{array}$ & (Maslach, 1982) \\
\hline & $\begin{array}{l}\text { It is possible, though, for various practices to } \\
\text { reduce organizational performance. This can } \\
\text { happen, for example, when a repetitive training } \\
\text { is provided for the same employee, when } \\
\text { managers are biased in implementing team } \\
\text { compensations, and even when workers } \\
\text { are given flexible hours and consequently } \\
\text { the actual volume of their responsibilities } \\
\text { at work is reduced. }\end{array}$ & $\begin{array}{c}\text { (Becker, Huselid, } \\
\text { Pickus, \& Spratt, 1997) }\end{array}$ \\
\hline & $\begin{array}{l}\text { This study revealed that HPWPs have } \\
\text { negative consequences such as larger job } \\
\text { pressure, decreased quality production, } \\
\text { and rise in absenteeism. }\end{array}$ & $\begin{array}{l}\text { (Flores, Posthuma, } \\
\text { \& Campion, 2016) }\end{array}$ \\
\hline & $\begin{array}{l}\text { This paper found that HPWPs practices } \\
\text { are negatively linked with wellbeing } \\
\text { and healthy life. }\end{array}$ & $\begin{array}{l}\text { (Guerci, Hauff, } \\
\text { \& Gilardi, 2019) }\end{array}$ \\
\hline
\end{tabular}

the effects of HPWPs on organizational performance prompting many researchers to overlook the difficulties of HPWPs implementation that requires many prerequisites such as building trust, producing a compelling strategy, investing in human resources, and developing employees' competencies.

On the other hand, not all practices that are considered or listed under the umbrella of HPWPs can have positive effects, therefore, even in some analysis supporting the positive impact of HPWPs on organizational performance such as Combs, Liu, Hall, and Ketchen (2006), some practices did not have significant effects on performance such as performance appraisals and information sharing, since both practices depend more on the types and criticality of information. The style and the importance of the shared information will define the employee role and reaction. Therefore, the simple implementation of some practices might affect organizational performance while the effectiveness of the implementation 
might determine outcomes for others (Huselid, Jackson, \& Schuler, 1997) and (Rubel, Kee, \& Rimi, 2020). Finally, more research is needed to unveil all hidden aspects related to HPWPs. Whether HPWPs might embody positive results or carry negative remnants is dependent on the right combination of human resources and management practices.

\section{Contribution}

This paper tried to critically evaluate the previous publications related to HPWPs and their relationship with individual and organizational performance. The aim of this review paper is to solve some of the uncertainties associated with HPWPs, give a summary of the present literature covering this interesting topic, to summarize the extend previous research, and to explain existing studies visions, disparities, and potential research courses.

\section{Conclusion}

The balance between employees and employers' goals has been one of the crucial matters in organizations. Still, what is beyond doubt is that organizations are trying effortlessly to find the right package, model, or formula regardless of its appellation to ensure the highest levels of individual and organizational performance. Realistic evidence was explored showing the relationships between diverse work practices and organizational results. Despite the initial agreement to call the practices that lead to higher organizational performance by the name of "high performance work practices" (HPWPs), the challenge was to estimate the size of the link between those practices and organizational performance and in measuring the effects of HPWPs on organizational performance after their implementation. Several results lay to rest any doubt about the existence of such relationship, and more importantly, suggest that organizations can increase their performance after the use of HPWPs. Many of those researches reached collective conclusions: the positive organizational results are linked to the right bundle of selected HPWPs, the variation of HPWPs effects depend on the size, culture, structure, sector and other environmental factors, and the importance of putting the HPWPs into the organization systems is indispensable to improve overall performance. Organizations should adopt, implement, and commit to apply HPWPs in order to measure their influence on organizational performance. What was mentioned points out the need for organizations to emphasize the importance of using HPWPs because of their positive link with performance most of the time. However, even though HPWPs are largely perceived to have positive impact on organizational performance; the key to their success seems to be the way organizations listen to their human capital before selecting their practices. Yet, the exact combination of practices is still under discussion, and it needs study, time, and is subject to trial and error application. Additionally, most studies related to HPWPs explored mainly employees' positive attitudes neglecting some peripheral damaging effects such as employee burnout, stress, 
wellbeing, and management abuse. Moreover, there are many areas to explore in HPWPs construct mainly the comparison between the employee-employer benefits, the intensity of each high-performance practice impact, the costs associated with the use of HPWPs, and many more. Yet, it is also important to consider studies that show which conditions are more favourable for HPWPs implementation and the processes by which they may influence performance more. It is also essential that additional studies provide information on the situations in which HPWPs interventions can have an effect and where they do not (Grant \& Wall, 2009). Granting that HPWPs have sometimes undesirable outcomes and that some practices have stronger impact on performance than others; the academia is full of analysis, research, and studies that provide considerable pragmatic support and assert that the investment in HPWPs is imperative in contributing to the improvement of the organizational performance and employee's happiness at the same time. This review paper highlighted the crucial role of HPWPs on organizational performance, and therefore recommends that organizations should focus on the use of these practices to be able to achieve and meet their set targets, retain their talents, and keep their competitive edge. Implementing HPWPs represents a win-win situation to organizations regardless of some minor negative and solvable effects. Organizations should pay more attention to the employment of HPWPs for managing their employees, increasing performance, and retaining their talents. To guarantee that these results are attained, utmost care is required when designing and implementing HPWPs. Therefore, organizations and leaders need to make critical choices of the practices that have a genuine effect on employees' performance and on the broader organization outcome in order to attain a high-performance culture with clear standards, values, and sustainable engaging environment. The studies have shown that such HPWPs tend to be part of a tactic that stresses on high quality of products, services and engaged workforce. Those practices such as training, involvement, empowerment, communication, and rewards can work more effectively in combination. These groupings should be coherent to enable the practices to work collectively toward the enhancement of employee performance aligned with the organization. As per Tamkin (2004) the implementation of these practices is linked with business performance and can lead to a 20 to 40 per cent of productivity disparity between the organizations that apply them and those who do not apply them. Despite the importance of HPWPs topic it might be beneficial to highlight some real practices and their effect as a result it can help organizations uncover best practices. Additionally, sharing some HPWPs design methodologies would have been also beneficial to explain some visible implications. Lastly and unfortunately, thus far few organizations have adopted such practices and hopefully this article cane encourages them to do so.

\section{Conflicts of Interest}

The author declares no conflicts of interest regarding the publication of this paper. 


\section{References}

Akhtar, A., Nawaz, M. K., Mahmood, Z., \& Shahid, M. S. (2016). Impact of High performance Work Practices on Employees' Performance in Pakistan: Mediating Role of Employee Engagement. Pakistan Journal of Commerce and Social Sciences (PJCSS), 10, 708-724.

Alatailat, M., Elrehail, H., \& Emeagwali, O.L. (2019). High Performance Work Practices, Organizational Performance and Strategic Thinking. International Journal of Organizational Analysis, 27, 370-395. https://doi.org/10.1108/IJOA-10-2017-1260

Albrecht, S. L., Bakker, A. B., Gruman, J. A., Macey, W. H., \& Saks, A. M. (2015). Employee Engagement, Human Resource Management Practices and Competitive Advantage. Journal of Organizational Effectiveness: People and Performance, 2, 7-35. https://doi.org/10.1108/JOEPP-08-2014-0042

Appelbaum, E. (2000). Manufacturing Advantage: Why High-Performance Work Systems Pay Off. Cornell University Press.

Ashton, D. N., \& Sung, J. (2002). Supporting Workplace Learning for High Performance Working. International Labour Organization.

Beck, K., \& Wilson, C. (2000). Development of Affective Organizational Commitment: A Cross-Sequential Examination of Change with Tenure. Journal of Vocational Behavior, 56, 114-136. https://doi.org/10.1006/jvbe.1999.1712

Becker, B. E., Huselid, M. A., Pickus, P. S., \& Spratt, M. F. (1997). HR as a Source of Shareholder Value: Research and Recommendations. Human Resource Management, 36, 39-47. https://doi.org/10.1002/(SICI)1099-050X(199721)36:1<39::AID-HRM8>3.0.CO;2-X

Berg, P. (1999). The Effects of High Performance Work Practices on Job Satisfaction in the United States Steel Industry. Relations Industrielles/Industrial Relations, 54, 111-135. https://doi.org/10.7202/051222ar

Bowen, D. E. (1986). Managing Customers as Human Resources in Service Organizations. Human Resource Management, 25, 371-383. https://doi.org/10.1002/hrm.3930250304

Bowen, D. E. and Ostroff, C. (2004). Understanding HRM-Firm Performance Linkages: The Role of the "Strength" of the HRM System. Academy of Management Review, 29, 203-221. https://doi.org/10.5465/amr.2004.12736076

Boxall, P., \& Purcell, J. (2000). Strategic Human Resource Management: Where Have We Come from and Where Should We Be Going? International Journal of Management Reviews, 2, 183-203. https://doi.org/10.1111/1468-2370.00037

Capelli, P., \& Neumark, D. (2001). External Job Churning and Internal Job Flexibility. NBER Working Paper, 8111, p.2001.

Combs, J., Liu, Y., Hall, A., \& Ketchen, D. (2006). How Much do High-Performance Work Practices Matter? A Meta-Analysis of Their Effects on Organizational Performance. Personnel Psychology, 59, 501-528. https://doi.org/10.1111/j.1744-6570.2006.00045.x

Delery, J. E. (1998). Issues of Fit in Strategic Human Resource Management: Implications for Research. Human Resource Management Review, 8, 289-309. https://doi.org/10.1016/S1053-4822(98)90006-7

Faems, D., Sels, L., De Winne, S., \& Maes, J. (2005). The Effect of Individual HR Domains on Financial Performance: Evidence from Belgian Small Businesses. The International Journal of Human Resource Management, 16, 676-700. https://doi.org/10.1080/09585190500082790 
Flores, G. L., Posthuma, R.A., \& Campion, M. A. (2016). Managing the Risk of Negative Effects of High Performance Work Practices. Understanding the High Performance Workplace: The Line between Motivation and Abuse (pp. 15-38). Routledge.

Garg, N. \& Lal, B. (2015). Exploring the Linkage between Awareness and Perception of High-Performance Work Practices with Employee Well-Being at Workplace: A New Dimension for HRM. Jindal Journal of Business Research, 4, 81-100.

Garg, N. (2019). High Performance Work Practices and Organizational PerformanceMediation Analysis of Explanatory Theories. International Journal of Productivity and Performance Management, 68, 797-816. https://doi.org/10.1108/IJPPM-03-2018-0092

Godard, J. (2004). A Critical Assessment of the High-Performance Paradigm. British Journal of Industrial Relations, 42, 349-378. https://doi.org/10.1111/j.1467-8543.2004.00318.x

Grant, A. M., \& Wall, T. D. (2009). The Neglected Science and Art of Quasi-Experimentation: Why-To, When-To, and How-To Advice for Organizational Researchers. Organizational Research Methods, 12, 653-686. https://doi.org/10.1177/1094428108320737

Greiner, L. E. (1972). Evolution and Revolution as Organizations Grow. Harvard Business Review, 50, 37-46.

Guerci, M., Hauff, S., \& Gilardi, S. (2019). High Performance Work Practices and Their Associations with Health, Happiness and Relational Well-Being: Are There Any Tradeoffs? The International Journal of Human Resource Management, 1-31. https://doi.org/10.1080/09585192.2019.1695647

Guest, D. (2000). HR and the Bottom Line: Has the Penny Dropped. People Management, 20, 26-31.

Guest, D. E., Michie, J., Conway, N., \& Sheehan, M. (2003). Human Resource Management and Corporate Performance in the UK. British Journal of Industrial Relations, 41, 291-314. https://doi.org/10.1111/1467-8543.00273

Hartnell, C. A., Ou, A. Y., Kinicki, A. J., Choi, D., \& Karam, E. P. (2019). A meta-Analytic Test of Organizational Culture's Association with Elements of an Organization's System and Its Relative Predictive Validity on Organizational Outcomes. Journal of Applied Psychology, 104, 832. https://doi.org/10.1037/apl0000380

Huselid, M. A. (1995). The Impact of Human Resource Management Practices on Turnover, Productivity, and Corporate Financial Performance. Academy of Management Journal, 38, 635-672. https://doi.org/10.2307/256741

Huselid, M. A., Jackson, S. E., \& Schuler, R.S. (1997). Technical and Strategic Human Resources Management Effectiveness as Determinants of Firm Performance. Academy of Management Journal, 40, 171-188. https://doi.org/10.2307/257025

Ibidunn, S., Osibanjo, A. O., Adeniji, A. A., Salau, O. P., \& Falola, H. O. (2015). Talent Retention and Organizational Performance: A Competitive Positioning in Nigerian Banking Sector. Periodica Polytechnica Social and Management Sciences, 24, 1-13. https://doi.org/10.3311/PPso.7958

Karatepe, O. M., \& Olugbade, O. A. (2016). The Mediating Role of Work Engagement in the Relationship between High-Performance Work Practices and Job Outcomes of Employees in Nigeria. International Journal of Contemporary Hospitality Management, 28, 2350-2371. https://doi.org/10.1108/IJCHM-03-2015-0145

Karatepe, O.M., \& Vatankhah, S. (2015). High-Performance Work Practices, Career Satisfaction, and Service Recovery Performance: A Study of Flight Attendants. Tourism Review. 
Ketchen Jr, D. J., Crook, T. R., Todd, S. Y., Combs, J. G., \& Woehr, D. J. (2017). Managing Human Capital. The Oxford Handbook of Strategy Implementation (pp. 283-311). Oxford University Press.

Kling, J. (1995). High Performance Work Systems and Firm Performance. Monthly Labor Review, 118, 29.

Kroon, B., Van de Voorde, K., \& Van Veldhoven, M. J. P. M. (2009). Cross-Level Effects of High-Performance Work Practices on Burnout: TWO counteracting Mediating Mechanisms Compared. Personnel Review, 38, 509-525. https://doi.org/10.1108/00483480910978027

Lawler, E. E., Lawler III, E. E., Mohrman, S. A., \& Ledford, G. E. (1995). Creating High Performance Organizations.

Lee, Y., Mazzei, A., \& Kim, J. N. (2018). Looking for Motivational Routes for Employee-Generated Innovation: Employees' Scouting Behavior. Journal of Business Research, 91, 286-294. https://doi.org/10.1016/j.jbusres.2018.06.022

Maslach, C. (1982). Burnout: The Cost of Caring. ISHK.

McAlearney, A. S., Hefner, J., Robbins, J., \& Garman, A. N. (2016). Toward a High-Performance Management System in Health Care, Part 4: Using high-Performance Work Practices to Prevent Central Line-Associated Blood Stream Infections-A Comparative Case Study. Health Care Management Review, 41, 233-243. https://doi.org/10.1097/HMR.0000000000000067

Mihail, D. M., Mac Links, M., \& Sarvanidis, S. (2013). High Performance Work Systems in Corporate Turnaround: A German Case Study. Journal of Organizational Change Management.

Murphy, K., Torres, E., Ingram, W., \& Hutchinson, J. (2018). A Review of High Performance Work Practices (HPWPs) Literature and Recommendations for Future Research in the Hospitality Industry. International Journal of Contemporary Hospitality Management, 30, 365-388. https://doi.org/10.1108/IJCHM-05-2016-0243

Nasurdin, A. M., Ling, T. C., \& Khan, S. N. (2018). The Relation between Turnover Intention, High Performance Work Practices (HPWPs), and Organisational Commitment: A Study among Private Hospital Nurses in Malaysia. Asian Academy of Management Journal, 23, 23-51. https://doi.org/10.21315/aamj2018.23.1.2

Noblet, A. J., \& Rodwell, J. J. (2008). The Relationship between Organisational Justice and Job Stress: Insights, Issues and Implications. Occupational Health Psychology: European Perspectives on Research, Education and Practice, 3, 281-312.

Obeidat, S. M., Mitchell, R., \& Bray, M. (2016). The Link between High Performance Work Practices and Organizational Performance. Employee Relations. https://doi.org/10.1037/t53260-000

Ogbonnaya, C., \& Valizade, D. (2018). High Performance Work Practices, Employee Outcomes and Organizational Performance: A 2-1-2 Multilevel Mediation Analysis. The International Journal of Human Resource Management, 29, 239-259. https://doi.org/10.1080/09585192.2016.1146320

Parks, S. (1995). Improving Workplace Performance: Historical and Theoretical Contexts. Monthly Labor Review, 118, 18.

Pittino, D., Visintin, F., Lenger, T., \& Sternad, D. (2016). Are High Performance Work Practices Really Necessary in Family SMEs? An Analysis of the Impact on Employee Retention. Journal of Family Business Strategy, 7, 75-89.

https://doi.org/10.1016/j.jfbs.2016.04.002

Rauch, A. and Hatak, I. (2016). A Meta-Analysis of Different HR-Enhancing Practices 
and Performance of Small and Medium Sized Firms. Journal of Business Venturing, 31, 485-504.

Robineau, A., Ohana, M., \& Swaton, S. (2015). The Challenges of Implementing High Performance Work Practices in the Nonprofit Sector. Journal of Applied Business Research (JABR), 31, 103-114. https://doi.org/10.19030/jabr.v31i1.8994

Rubel, M. R. B., Kee, D. M. H., \& Rimi, N. N. (2020). High-Performance Work Practices and Medical Professionals' Work Outcomes: The Mediating Effect of Perceived Organizational Support. Journal of Advances in Management Research.

Russell, J. S., Terborg, J. R., \& Powers, M. L. (1985). Organizational Performance and Organizational Level Training and Support. Personnel Psychology, 38, 849-863. https://doi.org/10.1111/j.1744-6570.1985.tb00570.x

Safavi, H. P., \& Karatepe, O. M. (2018). High-Performance Work Practices and Hotel Employee Outcomes. International Journal of Contemporary Hospitality Management, 30, 1112-1133. https://doi.org/10.1108/IJCHM-07-2016-0367

Saridakis, G., Lai, Y., \& Cooper, C. L. (2017). Exploring the Relationship between HRM and Firm Performance: A Meta-Analysis of Longitudinal Studies. Human Resource Management Review, 27, 87-96.

Selden, S. C., \& Sowa, J. E. (2015). Voluntary Turnover in Nonprofit Human Service Organizations: The Impact of High Performance Work Practices. Human Service Organizations: Management, Leadership \& Governance, 39, 182-207. https://doi.org/10.1080/23303131.2015.1031416

Shin, D., \& Konrad, A. M. (2017). Causality between High-Performance Work Systems and Organizational Performance. Journal of Management, 43, 973-997.

https://doi.org/10.1177/0149206314544746

Sofijanova, E., \& Zabijakin-Chatleska, V. (2013). High Performance Work Practices and Organizational Performance: An Analysis of the Macedonian Food and Beverage Industry. XI International Scientific Conference "Management and Engineering 13", 23-26 June 2013, Sozopol, 634-647.

Sung, J., \& Ashton, D. N. (2005). High Performance Work Practices: Linking Strategy and Skills to Performance Outcomes. Department of Trade and Industry.

Tamkin, P. (2004). High Performance Work Practices (pp. 1-16). Institute for Employment Studies.

Thompson, M. (2000). The Competitiveness Challenge: The Bottom Line Benefits of Strategic Human Resources. Department of Trade and Industry.

Topcic, M., Baum, M., \& Kabst, R. (2016). Are High-Performance Work Practices Related to Individually Perceived Stress? A Job Demands-Resources Perspective. The International Journal of Human Resource Management, 27, 45-66. https://doi.org/10.1080/09585192.2015.1043136

Tregaskis, O., Daniels, K., Glover, L., Butler, P., \& Meyer, M. (2013). High Performance Work Practices and Firm Performance: A Longitudinal Case Study. British Journal of Management, 24, 225-244. https://doi.org/10.1111/j.1467-8551.2011.00800.x

Ulrich, D. (2016). HR at a Crossroads. Asia Pacific Journal of Human Resources, 54, 148-164. https://doi.org/10.1111/1744-7941.12104

Waqas, M. (2017). High Performance Work Practices: Buffer in Times of Job Insecurity. University of Science and Technology of China.

Wood, S., Van Veldhoven, M., Croon, M., \& de Menezes, L. M. (2012). Enriched Job Design, High Involvement Management and Organizational Performance: The Mediating Roles of Job Satisfaction and Well-Being. Human relations, 65, 419-445. 
https://doi.org/10.1177/0018726711432476

Wright, P. M., \& Boswell, W. R. (2002). Desegregating HRM: A Review and Synthesis of Micro and Macro Human Resource Management Research. Journal of Management, 28, 247-276. https://doi.org/10.1177/014920630202800302

Wright, P. M., Gardner, T. M., Moynihan, L. M., \& Allen, M. R. (2005). The Relationship between HR Practices and Firm Performance: Examining Causal Order. Personnel Psychology, 58, 409-446. https://doi.org/10.1111/j.1744-6570.2005.00487.x

Wu, N. L. (2011). High Performance Work Practices in Small and Medium-Sized Firms. Doctoral Dissertation, University of Nottingham.

Wu, N., Hoque, K., Bacon, N., \& Bou Llusar, J. C. (2015). High-Performance Work Systems and Workplace Performance in Small, Medium-Sized and Large Firms. Human Resource Management Journal, 25, 408-423.

https://doi.org/10.1111/1748-8583.12084 